\title{
Effect of compost and animal manure with phosphorus and zinc fertilizer on yield of seed potatoes
}

\author{
N. Taheri ${ }^{1}$, H.H. Sharif-Abad ${ }^{2}$, K. Yousefi ${ }^{3}$ and S. Roholla-Mousavi ${ }^{4 *}$ \\ ${ }^{1}$ Islamic Azad University, jiroft Branch, Iran. ${ }^{2}$ Research Institute of Forests and Rangelands, Tehran, Iran. \\ ${ }^{3}$ Kerman Agricultural and Natural Resources Research Centre Iran. ${ }^{4}$ Department of Agriculture, Payame Noor \\ Universtiy, PO BOX 19395-3697,Tehran,Iran. .Corresponding author: rr_mousavi@yahoo.com
}

\begin{abstract}
This study was carried out to investigate the effect of compost and manure with phosphorus and zinc on potato yield (Solanum tuberosum L.). The experiment was conducted in the Kerman agricultural and natural resources research centre (Iran) by using a factorial design in randomized complete block in two independent experiments with three replications. In the first experiments compost with phosphorus and zinc were used, and in second experiment animal manure with phosphorus and zinc were used. The three levels of compost $\left(0,10\right.$ and 20 ton ha $\left.{ }^{-1}\right)$ and same level of animal manure were used as main. Four levels of phosphorus $(0,75,150$ and $225 \mathrm{~kg}$ $\left.\mathrm{ha}^{-1}\right)$ and two levels of zinc ( 0 and $\left.50 \mathrm{~kg} \mathrm{ha}^{-1}\right)$ used as the sub factors. Results showed that the main factors of compost and animal manure application had no significant effect on any of the all evaluated traits in the experiments. Effect of zinc on number of small tubers was significant in the first experiment. The highest number of large tubers were found in 20 ton ha ${ }^{-1}$ compost $+225 \mathrm{~kg} \mathrm{ha}^{-1}$ phosphorus $+50 \mathrm{~kg} \mathrm{ha}^{-1} \mathrm{zinc}$ in first experiment and 20 ton ha ${ }^{-1}$ animal manure $+75 \mathrm{~kg} \mathrm{ha}^{-1}$ phosphorus + no zinc in second experiment. Tubers dry matter was significantly affected by the interaction effect of zinc and phosphorus, the maximum dry matter being obtained with the application of $225 \mathrm{~kg} \mathrm{ha}^{-1}$ phosphorus $+50 \mathrm{~kg} \mathrm{ha}^{-1}$ zinc.
\end{abstract}

Keywords: Organic manure, compost, dry matter, potato, tuber. 


\section{Introduction}

Environmental problems caused by irregular application of chemical fertilizers, inappropriate energy production methods and excessive consumption costs have all had harmful effects on biological cycles and destroyed farming stability systems; these factors altogether encourage the application of bio fertilizers (Kannayan, 2002). Sustainability and safety of food production associated with environmental protection and fair socio-economic interactions in the societies involved are the most important debates in many multidisciplinary issues of agriculture, ecology and environmental sciences. These topics have attracted attention of researchers, farmers, policymakers and other stakeholders worldwide. Since soil as a living entity is the basis of management in sustainable food production, enhancing soil productivity through utilization of organic fertilizers has been gaining significant importance in organic food production (Neeson, 2004). These organic sources have a profound effect on crop yield and quality (Toor et al., 2006). In organic farming composts, organic manures and their extracts are used for improving soil fertility and in combating pests and diseases (Khadem, et al., 2010; Barker and Bryson, 2006; Montemurro et al., 2005; Litterick et al., 2004; Abbasi et al., 2002). Organic manures and composts have been found to have a direct anti disease effect by stimulating competing micro organisms and also by inducing resistance to plant diseases (Brinton et al., 1996; Ghorbani et al., 2006). However, there are other contradicting evidences indicating the reverse impact of using these sources (Chauhan et al., 2000). The use of fertilizers and manure to enhance soil fertility and hence crop yield improvement is a traditional method being used quite long a go by farmers (Sandeen et al., 2003). On the other hand the use of compost on agricultural land can be important in products based on the principles of sustainable agriculture (Perez et al., 2007). Use of municipal compost affect on the economic and environmental factors, such as reducing transport costs and bury it, to support environmental laws, reduce the use of inorganic fertilizers and improved soils crop characteristics (Hargreaves et al., 2008). The compost enriched with chemical fertilizers in the field the ability to access the elements of high consumption caused by the products and can be increased ability to production and soil fertility (Ramadass et al., 2007). Positive role of compost application has been reported in many crops, garden and pasture (Marcote et al., 2001). The application of compost increased microbial activity, nitrogen concentration and grain yield (Tejada et al., 2003). Use of compost in the Mediterranean semi-arid lands increased nitrogen, phosphorus, potassium and organic carbon content in the rhizosphere (Caravaca et al., 2003). Application of manure in the soil causes soil hollow, increased water holding capacity in soil and improved it physical properties, besides increasing soil fertility, crop growth and thus the water use efficiency (Karlen and Camp, 1985). The application of compost improved seed germination and yield dry matter as compared to compost-free treatments (McCallum et al., 1998). Phosphorus is the second most important macro nutrient after nitrogen that plays significant role in physiological and biochemical reactions such as photosynthesis and transfer characteristics (Mehrvarz et al., 2008). Phosphorus fertilizers and manure in the soil increased phosphorus uptake by plants, through favoring production of carbonic acid, the acid that increases solubility of phosphate compounds in calcareous soils (Yosefi et al., 2011; Chien, 2003). Zinc is also one of the essential micronutrients required for crop growth since it is an important component carbonic anhydrase enzyme which is present in all photosynthetic tissues, and is also re- 
quired for chlorophyll biosynthesis (Mousavi, 2011; Mousavi et al., 2007; Graham et al., 2001). The purpose of the present study was to determine the effects of compost, animal manure, phosphorus and Zinc fertilizer on seed potatoes production.

\section{Materials and Methods}

\subsection{Description of the project site}

This experiment was carried out in 2009 at the Kerman Natural Resources and Agriculture Research Center, Iran, located in 56 $34^{\prime}$ longitude and $29^{\circ} 55^{\prime}$ latitude and, $2044 \mathrm{~m}$ altitude from sea level with an arid and semi-arid climate. The $\mathrm{pH}$ of soil was 7.15 with sandy-loamy texture, (physical and chemical properties of soil in experimental field were presented in Table 1). Experiment was conducted in factorial randomized complete block design in two independent experiments with three replications. In the first experiment compost, phosphorus and zinc fertilizer and in the second experiment, animal manure, phosphorus and zinc fertilizer was utilized. The treatments consisted of three levels of compost $(0,10$ and 20 ton $\left.\mathrm{ha}^{-1}\right)$, three levels of animal manure $(0,10$ and 20 ton $\left.\mathrm{ha}^{-1}\right)$ as the main factors, four levels of phosphorus fertilizer $\left(0,75,150\right.$ and $\left.225 \mathrm{~kg} \mathrm{ha}^{-1}\right)$ and two levels of zinc fertilizer ( 0 and $\left.50 \mathrm{~kg} \mathrm{ha}^{-1}\right)$ as the sub factors. Planting was done as rows in $75 \mathrm{~cm}$ wide rows with $25 \mathrm{~cm}$ spacing within-rows in February 2010. All operations such as irrigation, weed control and earthing up were done regularly during the growing season.

Table 1. Soil analysis result for physical and chemical characteristics

\begin{tabular}{|c|c|c|c|c|c|c|c|c|c|c|c|}
\hline \multirow{2}{*}{ Characteristic } & \multirow{2}{*}{$\begin{array}{c}\text { Soil } \\
\text { depth } \\
(\mathrm{cm})\end{array}$} & \multirow{2}{*}{$\underset{\text { Soil }}{\text { texture }}$} & \multirow{2}{*}{$\begin{array}{l}\text { OC } \\
(\%)\end{array}$} & \multirow{2}{*}{$\begin{array}{c}E C \\
\left(d S ~ m^{-1}\right)\end{array}$} & \multirow[t]{2}{*}{ pH } & $\mathbf{P}$ & $\mathbf{K}$ & Zn & $\mathrm{Fe}$ & Mn & $\mathrm{Cu}$ \\
\hline & & & & & & \multicolumn{6}{|c|}{$\left(\mathrm{mg} \mathrm{kg}^{-1}\right)$} \\
\hline Value & $0-30$ & $\begin{array}{l}\text { sandy- } \\
\text { loamy }\end{array}$ & 0.15 & 1.88 & 7.15 & 10.06 & 174.2 & 0.74 & 5.06 & 1.40 & 1.18 \\
\hline
\end{tabular}

\subsection{Crop sampling and calculation}

At the mid of July 2010 by harvesting $2.5 \mathrm{~m}^{2}$ from each plot plant dry matter, tuber weight, number of tubers per plant and tuber size were determined. Tubers of each plot were graded into three size categories (small tuber $(<30 \mathrm{~mm})$, medium tuber $(30-60 \mathrm{~mm})$ and large tuber $(>60 \mathrm{~mm}))$.

\subsection{Statistical analysis}

Data analysis was done by using SAS and MSTATC software. The ANOVA test was used to determine sig- nificant $(p \leq 0.05)$ treatment effect and Duncan Multiple Range Test to determine significant difference between individual means.

\section{Results and discussion}

\subsection{First Experiment (effect of compost, phosphorus and zinc fertilizer on potato yield)}

Results showed that compost and phosphorus fertilizer application had no significant effect on traits (Table 2), also application of zinc fertilizer had no significant effects on traits except number of small 
tubers. Mean comparison showed that number of small tubers increased by application of zinc fertilizer compared with no zinc fertilizer (Figure 1). The most number of small tubers were obtained by use of $50 \mathrm{~kg} \mathrm{ha}^{-1}$ zinc. It seems that tuber buds increased by use of zinc fertilizer. The small tubers of potato do not have a good quality, so high application of zinc fertilizer was not useful for potatoes. Shoot dry matter significantly affected by compost, zinc and phosphate fertilizer interactions. Maximum shoot dry matter $(52.7 \mathrm{~g})$ was obtained by use of compost (10 ton $\left.\mathrm{ha}^{-1}\right)$, phosphorus (150 $\left.\mathrm{kg} \mathrm{ha}^{-1}\right)$ and no zinc fertilizer; also minimum shoot dry matter (17 g) was obtained by control treatment and application of compost (10 ton $\mathrm{ha}^{-1}$ ) and no phosphorus and zinc fertilizer (Figure 2). Main effect of compost, phosphorus and zinc fertilizer were not significant on shoot dry matter (Table 2). Potato shoot dry matter increased by compost application, due to improved soil structure and ventilation, and thereby tubers development increased in the better soil bed. Soil resistance against to tubers growth was reduced by compost application (Tu et al., 2006; Arancon et al., 2003).

Table 2. ANOVA of the effects of compost with phosphorus and zinc fertilizer on potato yield.

\begin{tabular}{|c|c|c|c|c|c|c|c|}
\hline \multirow{2}{*}{ SOV } & \multirow[b]{2}{*}{ df } & \multirow{2}{*}{$\begin{array}{l}\text { Shoot dry } \\
\text { matter } \\
\text { (g) }\end{array}$} & \multirow{2}{*}{$\begin{array}{c}\text { Tuber } \\
\text { weight } \\
\left(\mathrm{kg} \mathrm{m}^{-2}\right)\end{array}$} & \multicolumn{3}{|c|}{$\begin{array}{c}\text { Tuber number/ Tuber total number } \\
(\%)\end{array}$} & \multirow{2}{*}{$\begin{array}{c}\text { Number of } \\
\text { tuber } \\
\text { per plant }\end{array}$} \\
\hline & & & & Large tuber & $\begin{array}{l}\text { Medium } \\
\text { tuber }\end{array}$ & $\begin{array}{l}\text { Small } \\
\text { tuber }\end{array}$ & \\
\hline $\begin{array}{l}\text { Compost } \\
\text { (A) }\end{array}$ & 2 & $1036.00 \mathrm{~ns} 1$ & $0.141 \mathrm{~ns}$ & $30.10 \mathrm{~ns}$ & $100.5 \mathrm{~ns}$ & $53.40 \mathrm{~ns}$ & $6.68 \mathrm{~ns}$ \\
\hline Error 1 & 4 & 428.10 & 1.743 & 366.20 & 554.4 & 52.90 & 4.58 \\
\hline $\mathrm{P}(\mathrm{B})$ & 3 & $199.50 \mathrm{~ns}$ & $0.743 \mathrm{~ns}$ & $86.90 \mathrm{~ns}$ & $133.3 \mathrm{~ns}$ & $47.70 \mathrm{~ns}$ & $3.50 \mathrm{~ns}$ \\
\hline $\mathrm{A} \times \mathrm{B}$ & 6 & $53.57 \mathrm{~ns}$ & $0.764 \mathrm{~ns}$ & $35.00 \mathrm{~ns}$ & $82.2 \mathrm{~ns}$ & $35.50 \mathrm{~ns}$ & $4.11 \mathrm{~ns}$ \\
\hline $\mathrm{Zn}(\mathrm{C})$ & 1 & $4.50 \mathrm{~ns}$ & $0.175 \mathrm{~ns}$ & $2.47 \mathrm{~ns}$ & $172.7 \mathrm{~ns}$ & $133.90^{*}$ & $1.68 \mathrm{~ns}$ \\
\hline $\mathrm{A} \times \mathrm{C}$ & 2 & $42.79 \mathrm{~ns}$ & $0.094 \mathrm{~ns}$ & $30.80 \mathrm{~ns}$ & $23.8 \mathrm{~ns}$ & $39.70 \mathrm{~ns}$ & $5.26 \mathrm{~ns}$ \\
\hline $\mathrm{B} \times \mathrm{C}$ & 3 & $257.50 \mathrm{~ns}$ & $0.180 \mathrm{~ns}$ & $1.86 \mathrm{~ns}$ & $58.5 \mathrm{~ns}$ & $58.00 \mathrm{~ns}$ & $1.98 \mathrm{~ns}$ \\
\hline $\mathrm{A} \times \mathrm{B} \times \mathrm{C}$ & 6 & $341.20 *$ & $0.421 \mathrm{~ns}$ & $31.30 \mathrm{~ns}$ & $47.4 \mathrm{~ns}$ & $38.50 \mathrm{~ns}$ & $6.62 \mathrm{~ns}$ \\
\hline Error 2 & 42 & 142.90 & 0.423 & 42.50 & 88.9 & 44.2 & 5.28 \\
\hline
\end{tabular}

1 - ns $=$ Non significant and $*=p<0.05$ 


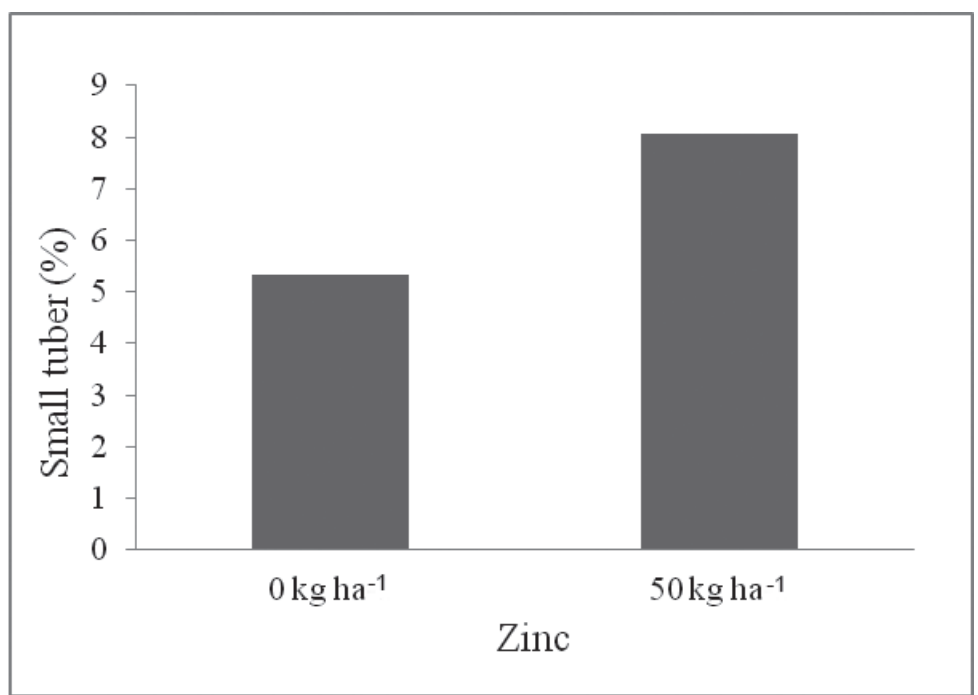

Figure 1. Effect of zinc fertilizer on number of small tuber.

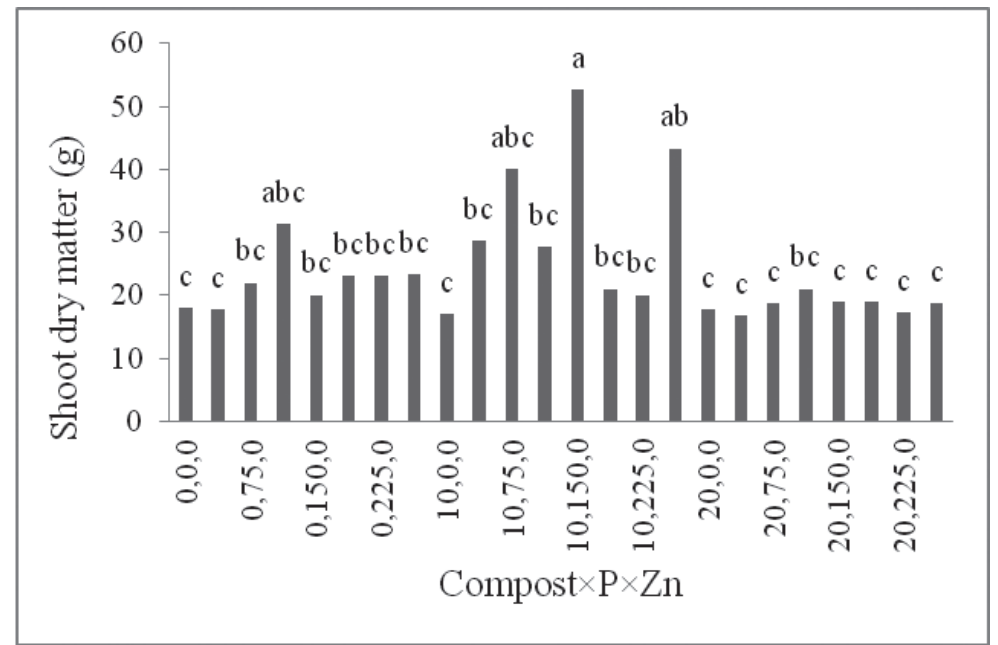

Figure 2. Effects of compost, phosphorus and zinc fertilizer interaction on shoot dry matter (same letter are not significantly different at 0.05 probability level).

3.2 Second Experiment (effect of manure, phosphorus and zinc fertilizer on potato yield)

Results showed that manure application had on significant effect on traits (Table 3). It seems that manure application was not enough to have a significant effect on the traits; also main effect of phosphorus fertilizer wasn't significant on potato yield. Zinc fertilizer except on the number of tubers per plant had no significant effect on the other traits (Table 3). Zinc fertilizer 
decreased number of tubers per plant significantly $(p<0.05)$ (Table 4). Most tuber weight was $1.85 \mathrm{~kg} \mathrm{~m}^{2}$ that obtained by use of $150 \mathrm{~kg} \mathrm{ha}^{-1}$ phosphorus fertilizer without manure (Figure 3). Most number of small tubers $(6.15 \%)$ was obtained by use of 10 ton $^{-1}$ manure treatments without zinc fertilizer and least number of small tubers $(1.32 \%)$ was obtained by no fertilizer and manure treatment (Figure 4); there were no significantly different between other treatments. Most number of tubers per plant (7.74) was obtained by application of 10 ton ha ${ }^{-1}$ manure without zinc fertilizer; also lowest number of tubers per plant was obtained by other treatments, without significant differences (Figure 5). Shoot dry matter, tuber weight and ratio of large and medium tuber to total number significantly affected by zinc and phosphorus interac- tion (Table 3). Maximum shoot dry matter per plant $(28.7 \mathrm{~g})$ was obtained by use of $225 \mathrm{~kg} \mathrm{ha}^{-1}$ phosphorus and $50 \mathrm{~kg} \mathrm{ha}^{-1}$ zinc; also minimum shoot dry matter per plant $(20 \mathrm{~g})$ was obtained by use of 225 $\mathrm{kg} \mathrm{ha}^{-1}$ phosphorus and no zinc fertilizer. Maximum and minimum ratio of large tuber was obtained by use of $75 \mathrm{~kg} \mathrm{ha}^{-1}$ phosphorus without zinc and $225 \mathrm{~kg}$ ha $^{-1}$ phosphorus without zinc respectively (Table 4). Maximum ratio of medium tuber was obtained by use of $\mathrm{kg} \mathrm{ha}^{-1}$ phosphorus without zinc fertilizer (Table 4). Microorganism's activity is low in poor soils of organic matter; thereupon speed of organic material decomposition decreased by decreasing the populations of microorganisms. Compost and manure had no significant influence on potato yield because population of microorganisms was low in the field experimental

Table 3. ANOVA of the effects of manure with phosphorus and zinc fertilizer on potato yield.

\begin{tabular}{|c|c|c|c|c|c|c|c|}
\hline \multirow[b]{2}{*}{ SOV } & \multirow[b]{2}{*}{ df } & \multirow{2}{*}{$\begin{array}{l}\text { Shoot dry } \\
\text { matter } \\
\text { (g) }\end{array}$} & \multirow{2}{*}{$\begin{array}{l}\text { Tuber Weight } \\
\qquad\left(\mathrm{kg} \mathrm{m}^{-2}\right)\end{array}$} & \multicolumn{3}{|c|}{$\begin{array}{c}\text { Tuber number/ Tuber total number } \\
\qquad(\%)\end{array}$} & \multirow{2}{*}{$\begin{array}{c}\text { Number of } \\
\text { tuber } \\
\text { per plant }\end{array}$} \\
\hline & & & & $\begin{array}{l}\text { Large } \\
\text { tuber }\end{array}$ & $\begin{array}{c}\text { Medium } \\
\text { tuber }\end{array}$ & $\begin{array}{l}\text { Small } \\
\text { tuber }\end{array}$ & \\
\hline Manure (A) & 2 & $530.80 \mathrm{~ns} 1$ & $0.139 \mathrm{~ns}$ & $9.44 \mathrm{~ns}$ & $51.94 \mathrm{~ns}$ & $28.89 \mathrm{~ns}$ & $4.66 \mathrm{~ns}$ \\
\hline Error 1 & 4 & 396.20 & 0.092 & 16.30 & 27.07 & 39.41 & 1.82 \\
\hline $\mathrm{P}(\mathrm{B})$ & 3 & $12.61 \mathrm{~ns}$ & $0.190 \mathrm{~ns}$ & $22.36 \mathrm{~ns}$ & $40.51 \mathrm{~ns}$ & $13.45 \mathrm{~ns}$ & $0.97 \mathrm{~ns}$ \\
\hline$A \times B$ & 6 & $86.49 \mathrm{~ns}$ & $0.334 *$ & $50.84 \mathrm{~ns}$ & $58.12 \mathrm{~ns}$ & $8.66 \mathrm{~ns}$ & $3.27 \mathrm{~ns}$ \\
\hline $\mathrm{Zn}(\mathrm{C})$ & 1 & $46.31 \mathrm{~ns}$ & $0.127 \mathrm{~ns}$ & $3.70 \mathrm{~ns}$ & $10.49 \mathrm{~ns}$ & $1.73 \mathrm{~ns}$ & $20.26^{*}$ \\
\hline $\mathrm{A} \times \mathrm{C}$ & 2 & $34.62 \mathrm{~ns}$ & $0.029 \mathrm{~ns}$ & $97.52 \mathrm{~ns}$ & $79.43 \mathrm{~ns}$ & $52.15^{*}$ & $11.50^{*}$ \\
\hline $\mathrm{B} \times \mathrm{C}$ & 3 & $175.70 *$ & $0.391 *$ & $131.10^{*}$ & $202.00 *$ & $10.17 \mathrm{~ns}$ & $4.68 \mathrm{~ns}$ \\
\hline $\mathrm{A} \times \mathrm{B} \times \mathrm{C}$ & 6 & $13.42 \mathrm{~ns}$ & $0.122 \mathrm{~ns}$ & $32.03 \mathrm{~ns}$ & $22.03 \mathrm{~ns}$ & $8.92 \mathrm{~ns}$ & $1.35 \mathrm{~ns}$ \\
\hline Error 2 & 42 & 48.62 & 0.109 & 34.96 & 51.97 & 19.08 & 3.30 \\
\hline
\end{tabular}

1 - $\mathrm{ns}=$ Non significant and $*=p<0.05$ 
Table 4. Means comparison of interaction effects of phosphorus and zinc fertilizer on dry matter, tuber weight, ratio of tuber and tuber number per plant.

\begin{tabular}{|c|c|c|c|c|c|c|c|}
\hline \multirow{2}{*}{\multicolumn{2}{|c|}{$\begin{array}{c}\text { Traits } \\
\text { Treatments }\end{array}$}} & \multirow{3}{*}{$\begin{array}{c}\begin{array}{l}\text { Shoot dry } \\
\text { matter (g) }\end{array} \\
21.4 \mathrm{ab} 1\end{array}$} & \multirow{3}{*}{$\begin{array}{c}\begin{array}{c}\text { Tuber } \\
\text { weight } \\
\left(\mathbf{k g ~ m}^{-2}\right)\end{array} \\
1.79 \mathrm{a}\end{array}$} & \multicolumn{3}{|c|}{$\begin{array}{c}\text { Tuber number/ Tuber total } \\
\text { number }(\%)\end{array}$} & \multirow{3}{*}{$\begin{array}{c}\begin{array}{c}\text { Number of } \\
\text { tuber } \\
\text { per plant }\end{array} \\
7.22\end{array}$} \\
\hline & & & & \multirow{2}{*}{\begin{tabular}{c|}
$\begin{array}{c}\text { Large } \\
\text { tuber }\end{array}$ \\
$9.83 \mathrm{abc}$ \\
\end{tabular}} & \multirow{2}{*}{\begin{tabular}{c|}
$\begin{array}{c}\text { Medium } \\
\text { tuber }\end{array}$ \\
$85.70 \mathrm{ab}$ \\
\end{tabular}} & \multirow{2}{*}{$\begin{array}{c}\begin{array}{c}\text { Small } \\
\text { tuber }\end{array} \\
4.47\end{array}$} & \\
\hline D $(01$ l & $\mathrm{Zn}\left(0 \mathrm{~kg} \mathrm{ha}^{-1}\right)$ & & & & & & \\
\hline$P(0 \mathrm{~kg}$ nd $)$ & $\mathrm{Zn}\left(50 \mathrm{~kg} \mathrm{ha}^{-1}\right)$ & $25.9 \mathrm{ab}$ & $1.36 \mathrm{~b}$ & $7.16 \mathrm{bc}$ & $90.10 \mathrm{a}$ & 2.69 & 5.22 \\
\hline \multirow{2}{*}{$\mathrm{P}\left(75 \mathrm{~kg} \mathrm{ha}^{-1}\right)$} & $\mathrm{Zn}\left(0 \mathrm{~kg} \mathrm{ha}^{-1}\right)$ & $27.5 \mathrm{ab}$ & $1.40 \mathrm{~b}$ & $14.22 \mathrm{a}$ & $81.30 \mathrm{~b}$ & 4.52 & 5.99 \\
\hline & $\mathrm{Zn}\left(50 \mathrm{~kg} \mathrm{ha}^{-1}\right)$ & $21.9 \mathrm{ab}$ & $1.42 . \mathrm{b}$ & $8.01 \mathrm{abc}$ & $88.90 \mathrm{ab}$ & 3.09 & 5.33 \\
\hline \multirow{2}{*}{$P\left(150 \mathrm{~kg} \mathrm{ha}^{-1}\right)$} & $\mathrm{Zn}\left(0 \mathrm{~kg} \mathrm{ha}^{-1}\right)$ & $23.3 \mathrm{ab}$ & $1.54 \mathrm{ab}$ & $10.15 \mathrm{abc}$ & $87.00 \mathrm{ab}$ & 2.90 & 5.78 \\
\hline & $\mathrm{Zn}\left(50 \mathrm{~kg} \mathrm{ha}^{-1}\right)$ & $22.2 \mathrm{ab}$ & $1.70 \mathrm{ab}$ & $10.72 \mathrm{abc}$ & $85.50 \mathrm{ab}$ & 3.80 & 5.96 \\
\hline \multirow{2}{*}{$\mathrm{P}\left(225 \mathrm{~kg} \mathrm{ha}^{-1}\right)$} & $\mathrm{Zn}\left(0 \mathrm{~kg} \mathrm{ha}^{-1}\right)$ & $20.0 \mathrm{~b}$ & $1.51 \mathrm{ab}$ & $5.58 \mathrm{c}$ & $92.10 \mathrm{a}$ & 1.35 & 6.78 \\
\hline & $\mathrm{Zn}\left(50 \mathrm{~kg} \mathrm{ha}^{-1}\right)$ & $28.7 \mathrm{a}$ & $1.38 \mathrm{~b}$ & $13.07 \mathrm{ab}$ & $84.50 \mathrm{ab}$ & 2.43 & 5.00 \\
\hline
\end{tabular}

1- Columns means followed by the same letter are not significantly different at 0.05 probability level.

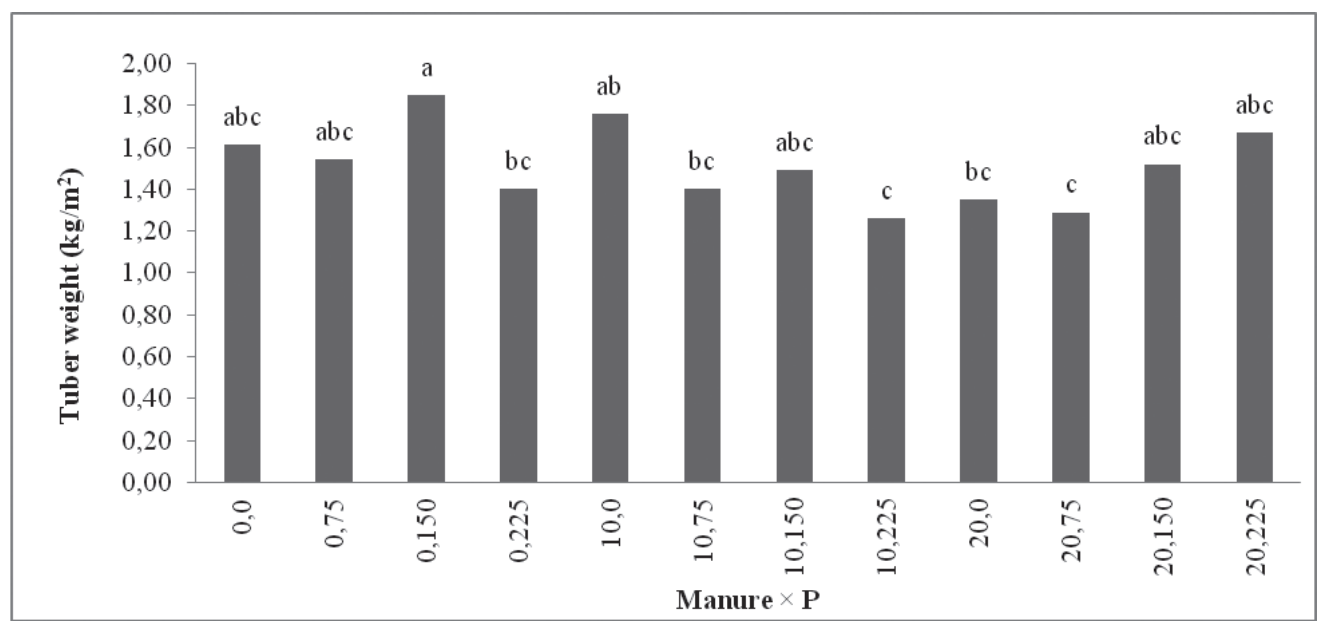

Figure 3. Effects of manure and phosphorus interaction on tuber weight (same letter are not significantly different at 0.05 probability level). 


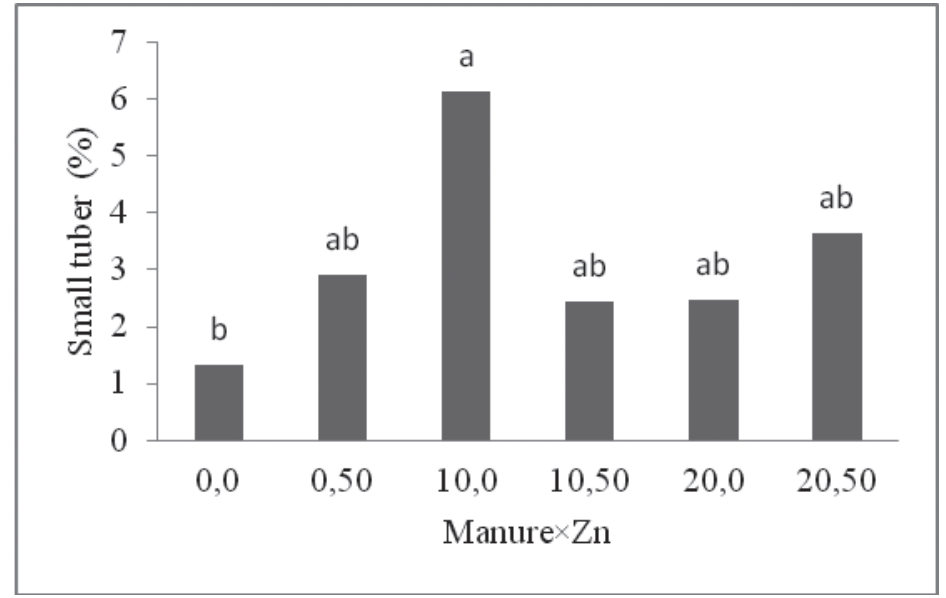

Figure 4. Effects of manure and zinc interaction on ratio of small tuber (same letter are not significantly different at 0.05 probability level).

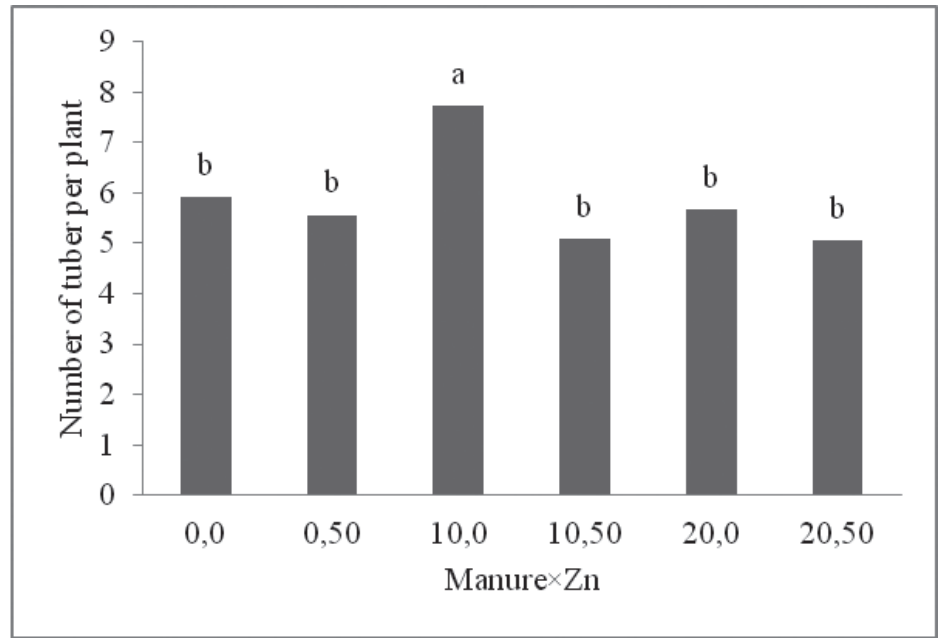

Figure 5. Effects of manure and zinc interaction on number of tuber per plant (same letter are not significantly different at 0.05 probability level).

\section{Conclusion}

In this research compost and manure had no considerable significant effect on potato yield, because experimental soil field was poor of organic matter, so application of this amount of compost and manure could not have a high effect on potato yield. Animal manure and compost was improves the soil physical characteristics over several years. This research was done for a crop year, so the influence of compost and manure were not evident in the first year. According to the result application of zinc fertilizer increased percent of small tuber, so application of zinc fertilizer is not recommended for seed potatoes production. 


\section{References}

Abbasi, P.A., Al-Dahmani, J., Sahin, F., Hoitink, H.A.J., Miller, S.A. 2002. Effect of compost amendments on disease severity and yield of tomato in conventional and organic production systems. Plant Disease. 86, 156-161.

Arancon, N.Q., Edwards, C.A., Bierman, P.J., Metzger, D., Lee, S., Welch, C. 2003. Effects of vermin composts on growth and marketable fruits of field-grown tomatoes, peppers and strawberries. Pedobiologia. 47, 731-735.

Barker, A.V., Bryson, G.M. 2006. Comparisons of composts with low or high nutrient status for growth of plants in containers. Comm. Soil Sci. Plant Ana. 37, 1303-1319.

Brinton, W.F., Trankner, A., Roffner, M. 1996. Investigations into liquid compost extracts. Biocycle. 37, 68-70.

Caravaca, F., Figueroa, D., Alguacil, M.M., Rolan, A. 2003. Application of composted urban residue enhanced the performance of afforested shrub species in a degraded semiarid Land. Biores. Technol. 90, 65-70.

Chauhan, R.S., Maheshwari, S.K., Gandhi, S.K. 2000. Effect of nitrogen, phosphorus and farm yard manure levels on stem rot of cauliflower caused by Rhizoctonia solani. Agri. Sci. Digest. 20, 36-38.

Chien, S.H. 2003. Factors affecting the agronomic effectiveness of phosphate rock for direct application. In direct application of phosphate rock and related technology: latest development and practical experiences, pp.50-62, (S.S.S. Rajan and S.H. Chien, ed.). Special Publications IFDCSP- 37, IFDC, Muscle Shoals, Alabama.

Ghorbani, R., Wilcockson, S., Leifert, C. 2006. Alternative treatments for late blight control in organic potato: Antagonistic micro-organisms and compost extracts for activity against Phytophthora infestans. Potato Research. 48, 171-179.
Graham, R.D., Welch, R.M., Bouis, H.E. 2001. Addressing micronutrient nutrition through enhancing the nutritional quality of staple foods. Adv. Agron. 70, 77-142.

Hargreaves, J.C., Adl, M.S., Warman, P.R. 2008. A review of the use of composted municipal solid waste in agriculture. Agric. Ecosyst. Environ. 123, 1-14.

Kannayan, S. 2002. Biofertilizers for sustainable crop production, Biothecnology of biofertilizers. Narosa Publishing House, New Delhi, India 9-49.

Karlen, D.M., Camp, C.R. 1985. Row spacing plant population, and water management effect on corn in the in the Atlanta coastal plain. Agronom. J. 77, 393-398.

Khadem, S.A., Galavi, M., Ramrodi, M., Mousavi, S.R., Rousta, M.J., Rezvani-Moghadam, P. 2010. Effect of animal manure and superabsorbent polymer on corn leaf relative water content, cell membrane stability and leaf chlorophyll content under dry condition. Aus. J. Crop Sci. 4,8, 642-647.

Litterick, A.L., Harrier, L., Walllace, P., Watson, C.A., Wood, M. 2004. The role of un-composted materials, composts, manures, and compost extracts in reducing pest and disease incidence and severity in sustainable temperate agricultural and horticultural crop production - a review. Crit. Rev. Plant Sci. 23, 453-479.

Marcote, I., Hernandez, T., Garcia, C., Polo, A. 2001. Influence one or two successive annual application of organic fertilizers on the enzyme activity of a soil under barley cultivation. Biores. Technol. $79,147-154$.

Mc-Callum, K.R., Keeling, A.A., Beckwith, C.P., Kettlewell, P.S. 1998. Effects of greenwaste compost on spring wheat emergence and early growth. Acta Hort. 467, 313-31.

Mehrvarz, S., Chaichi, M.R., Alikhani, H.A. 2008. Effect of Phosphate solubilizing microorganisms 
and phosphorus chemical fertilizer on forage and grain quality of barely (Hordeum vulgare L). Amer-Eurasian J. Agri. Environ. Sci. 3, 855-860.

Montemurro, F., Convertini, G., Ferri, D., Maiorana, M. 2005. MSW compost application on tomato crops in Mediterranean conditions: Effects on agronomic performance and nitrogen utilization. Compost Sci. Utiliz. 13, 234-242.

Mousavi, S.R. 2011. Zinc in crop production and interaction with phosphorus. Aust. J. Basic \& Appl. Sci. 5(9), 1503-1509.

Mousavi, S.R., Galavi, M., Ahmadvand, G. 2007. Effect of zinc and manganese foliar application on yield, quality and enrichment on potato (Solanum tuberosum L.). Asian J. Plant Sci. 6, 1256-1260.

Neeson, R, 2004. Organic processing tomato production. Agfact H8.3.6, first edition.

Perez, D.V., Alcantara, S., Ribeiro, C.C., Pereira, R.E., Fontes, G.C., Wasserman, M.A., Venezuela, T.C., Meneguelli, N.A., de Macedo, J.R. C., Barradas, A.A. 2007. Composted municipal waste effects on chemical properties of a Brazilian soil. Bioresour. Technol. 98, 525-533.
Ramadass, K., Palaniyandi, S. 2007. Effect of enriched municipal solid waste compost application on soil available macronutrients in the rice field. Arch. Agron. Soil Sci. 53, 497-506.

Sandeen, A., Gamroth, M. 2003. Composting, an alternative for livestock manure management and disposal of dead animals. EM 8825 Murch 2003. Oregon state university

Tejada, M., Gonzalez, J. 2003. Effects of the application of a compost originating from crushed cotton gin residues on wheat yield under dry land conditions. Eur. J. Agron. 19, 357-368.

Tu, C., Ristaino, J.B., Hu, S. 2006. Soil microbial biomass and activity in organic tomato farming systems: Effects of organic inputs and straw mulching. Soil Biol. Biochem. 38, 247-255.

Yosefi K., Galavim M., Ramrodim M., Mousavi, S.R. 2011. Effect of bio-phosphate and chemical phosphorus fertilizer accompanied with micronutrient foliar application on growth, yield and yield components of maize (Single Cross 704). Aus. J. Crop Sci. $5,2,175-180$ 